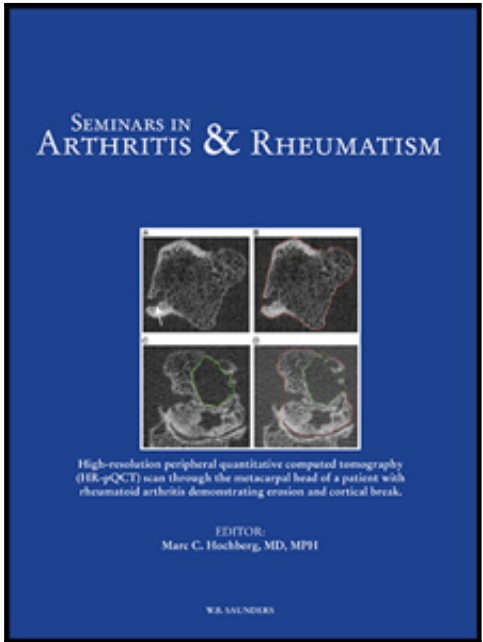

\title{
ANTIPHOSPHOLIPID ANTIBODIES AND RENAL TRANSPLANT: A SYSTEMATIC REVIEW AND META-ANALYSIS
}

Paul RJ Ames MD, MSc, PhD , Mira Merashli MD , Tommaso Bucci MD , Fabrizio Gentile MD, PhD , Jose' Delgado Alves MD, PhD

PII: S0049-0172(18)30591-2

DOI: https://doi.org/10.1016/j.semarthrit.2018.10.016

Reference: YSARH 51412

To appear in:

Seminars in Arthritis \& Rheumatism

Please cite this article as: Paul RJ Ames MD, MSc, PhD, Mira Merashli MD, Tommaso Bucci MD , Fabrizio Gentile MD, PhD , Jose' Delgado Alves MD, PhD , ANTIPHOSPHOLIPID ANTIBODIES AND RENAL TRANSPLANT: A SYSTEMATIC REVIEW AND META-ANALYSIS, Seminars in Arthritis \& Rheumatism (2018), doi: https://doi.org/10.1016/j.semarthrit.2018.10.016

This is a PDF file of an unedited manuscript that has been accepted for publication. As a service to our customers we are providing this early version of the manuscript. The manuscript will undergo copyediting, typesetting, and review of the resulting proof before it is published in its final form. Please note that during the production process errors may be discovered which could affect the content, and all legal disclaimers that apply to the journal pertain. 


\section{ANTIPHOSPHOLIPID ANTIBODIES AND RENAL TRANSPLANT:}

\section{A SYSTEMATIC REVIEW AND META-ANALYSIS}

by

Paul RJ Ames ${ }^{1,2,3,}$ MD, MSc, PhD, Mira Merashli ${ }^{4}$, MD, Tommaso Bucci, ${ }^{5}$ MD, Fabrizio Gentile $^{6}$, MD, PhD, Jose' Delgado Alves ${ }^{1}, \mathrm{MD}, \mathrm{PhD}$.

${ }^{1}$ CEDOC, NOVA Medical School/Faculdade de Ciências Médicas, Universidade NOVA de Lisboa, Lisboa, Portugal; ${ }^{2}$ Department of Haematology, Dumfries Royal Infirmary, Scotland, UK $;{ }^{3}$ Multimedica, Naples, Italy;

${ }^{4}$ Department of Rheumatology, American University of Beirut, Beirut, Lebanon;

${ }^{5}$ Department of Internal Medicine, Division of Allergy and Clinical Immunology, University of Salerno, Baronissi, Italy;

${ }^{6}$ Department of Medicine \& Health Sciences, Universita' del Molise, Campobasso, Italy.

Corresponding author: Immune Response and Vascular Disease Unit, CEDOC, Nova University, Rua Câmara Pestana 6, 1150-082, Lisbon, Portugal; Phone: (+351) 218803038 (ext 22492); e-mail: paxmes@aol.com

Abstract

Objective. To evaluate the effect of antiphospholipid antibodies (aPL) on renal allograft outcome after kidney transplantation. Methods. A systematic search of EMBASE and PubMed databases from inception to July 2018 was run according to PRISMA guidelines; Peto's odds ratio (OR) for rare events was used for the meta-analysis. Results. Our inclusion/exclusion criteria were met by 22 cohort studies having different outcomes: allograft thrombosis $(n=9)$ and thromboprophylaxis $(n=3)$, allograft loss from any cause $(n=9)$, allograft malfunction $(n=3)$, duration $(n=2)$, glomerular filtration rate at 1 year $(n=3)$ and allograft rejection $(n=5)$. The pooled prevalence of allograft thrombosis and of thrombotic microangiopathy was greater in aPL+ve than negative recipients $(10.4 \%$ vs $1.7 \%$, 
$\mathrm{p}<0.0001$ and $10.2 \%$ vs $0 \%, \mathrm{p}=0.005$ respectively). The pooled prevalence of allograft thrombosis was $75 \%$ in patients not taking anticoagulation whereas none of the anticoagulated recipients developed thrombosis $(\mathrm{p}<0.0001)$. The pooled prevalence of allograft loss was greater in aPL+ve recipients ( $28 \%$ vs $18 \%$ respectively, $\mathrm{p}<0.0001)$; the pooled prevalence of aPL was greater in allograft loss recipients compared to those who did not lose it $(51 \%$ vs $33 \%, \mathrm{p}<0.0001)$. The pooled prevalence of allograft malfunction and rejection was similar in aPL-ve and aPL+ve recipients $(32.2 \%$ vs $40.3 \%$ and $14.9 \%$ vs $14.4 \%$ respectively) but graft duration was shorter in aPL+ve than aPL-ve recipients $(p=0.001)$ and glomerular filtration rate at 1 year was lower in aPL+ve than aPL-ve recipients $(\mathrm{p}<0.0001)$. Conclusion: APL relate strongly to allograft thrombosis, loss and duration but not to allograft malfunction and rejection. Oral antivitamin $\mathrm{K}$ anticoagulants effectively prevent allograft thrombosis in aPL recipients. The debate on the role of aPL in renal transplant is limited by the expression of data as percentage of recipients positive for aPL rather than aPL titres in many studies.

Key words: antiphospholipid antibodies, renal transplantation

\section{Introduction}

The presence and persistence of antiphospholipid antibodies (aPL) detected via immune or clotting assays in association with vascular occlusions in either arterial or venous districts characterises the antiphospholipid syndrome (APS): in isolation it is defined primary APS, in association to other autoimmune disease including systemic lupus erythematosus it is defined as secondary (1). While renal artery stenosis and thrombosis, renal infarction, renal vein thrombosis and chronic nephropathy are recognised features of kidney involvement in the APS (2), the role of aPL in kidney transplantation is less clear given the varying types of 
studies performed, the different aPL measured and the different endpoints employed (3). We performed this systematic review to evaluate the outcome of renal allograft post kidney transplantation in recipients positive for aPL pre and/or post allograft; in particular the systematic review will try to answer two major questions: whether aPL influence the outcome of the renal allograft and whether anticoagulation affects allograft survival.

\section{Methods}

\section{Search strategy and selection criteria}

A systematic review according to the PRISMA guidelines [4] was carried out by searching the electronic databases MEDLINE and EMBASE from January 1985 to March 2018.; for the search strategy we used the terms ['renal 'OR 'kidney transplant '] and ['anticardiolipin' OR 'anti-beta 2-glycoprotein-I' OR 'antiphospholipid syndrome,' OR 'lupus anticoagulant' OR 'lupus inhibitor']. The same terms were used screen two data bases for grey literature, Open Grey and OAIster. The first search yielded 392 records plus another 3 found amongst the references screened for inclusion in the systematic review and the grey literature search yielded 7 references. Altogether the 412 were processed according to Figure 1.

PRJA is the guarantor. MM and JDA developed the search strategy. All authors contributed to the development of the selection and data extraction criteria; PRJA, JDA and FG screened the articles; PRJA/an MM extracted the data; PRJA and JDA drafted the manuscript. PRJA provided statistical expertise. FG provided expertise on immunology issues; all authors read, discussed and approved the final manuscript.

\section{Criteria for selecting articles}

Three investigators (PRJA, JDA and FG) screened all the retrieved papers for relevancy. Inclusion criteria were: 1) observational studies (cross-sectional, case-control and/or cohort) 
investigating: a) the difference in the prevalence of failed renal allografts, allograft thrombosis, allograft malfunction between kidney transplant recipients positive and negative for aPL, b) the difference in the prevalence of aPL positivity (and aPL) between renal transplant recipients with failed, malfunctioning and/or thrombosed allografts compared to recipients without these complications c) the difference in the prevalence of non renal thrombosis between renal allograft recipients positive and negative for aPL; 2) aPL measured by immune or clotting assays; 3) articles written in English, French and Spanish.If more than two studies investigated the same population, the latest or highest-quality study was chosen. Exclusion criteria were: 1) prevalence studies only; 2) studies investigating systemic lupus erythematosus (SLE); 3) non-original research; 4) studies not reporting the relationship between aPL and renal transplant; 5) articles not written in the languages indicated in the inclusion criteria.

\section{Evaluation of the quality of the studies}

The quality of the studies identified was assessed by the Newcastle Ottawa Quality Assessment Scale (NOQAS) for case control and cohort studies specifically developed to assess quality of observational studies; the studies included in the meta-analysis are mostly cross sectional simply comparing two different groups within the renal transplant cohorts, with or without certain clinical manifestations or with or without aPL and therefore lack a real exposure to qualify as true case control [5]. The NOQAS covers three major domains (selection of cases and controls, comparability of groups and ascertainment of either the exposure or outcome of interest) and the resulting score may range between 0 and 8 , a higher score representing a better methodological quality. Data were independently extracted into a standard electronic form and averaged and any discrepancies were resolved by consensus. 


\section{Outcome measures}

The primary outcomes were: 1) the comparative pooled prevalence of failed renal allografts, allograft thrombosis, allograft malfunction in aPL+ve and aPL-ve renal transplant patients (with odd ratios and level of significance); 2) the comparative pooled prevalence of aPL in participants with and without failed, malfunctioning and thrombosed renal allografts; 3) the standardized mean difference of aPL titres between the groups indicated in number two; 3) the comparative pooled prevalence of aPL in renal allograft recipients patients with and without systemic thrombosis, alternatively the pooled prevalence of systemic thrombosis in allograft recipients with and without aPL.

The secondary outcomes were: 1) the comparative prevalence of aPL in kidney transplant recipients pre-post allograft; 2) the efficacy of anticoagulation in preventing allograft thrombosis (or systemic thrombosis) indicated by the comparative prevalence of renal allograft thrombosis in aPL+ve recipients receiving anticoagulation compared to those recipients not receiving anticoagulation.

\section{Statistical analysis}

We employed random effects meta-analyses for continuous and categorical outcomes as the estimates did not derived from planned experiments but were the result of observational studies. The comparative pooled odds ratio between graft allograft outcomes in renal allograft recipients positive and negative for aPL was assessed by Peto's odds ratio as it the appropriate statistical method for rare events [6]. Subgroup analyses were based on clinical judgment. Statistical heterogeneity was estimated by $\mathrm{I}^{2}$ statistics: an $\mathrm{I}^{2}$ value of $0 \%$ indicated no heterogeneity; values less than $25 \%$ indicate low, between $25-50 \%$ moderate and over $50 \%$ high heterogeneity. We did not rely on funnel plots for their known fallacy in assessing publication bias $(7,8)$. The statistical analysis was carried out using Comprehensive Meta- 
Analysis, Biostat, USA; Cohen's kappa assessed the inter-rater scoring agreement of two investigators.

\section{SYSTEMATIC REVIEW RESULTS}

\section{Number and quality of the studies}

After completion of the screening and exclusion process (Figure 1) we identified 22 cohort studies exploring the relationship between aPL and renal transplant (9-31)(Table 1). A score of $\geq 7$ on the NOQAS arbitrarily defined a good study and only two studies had low score at 4; the inter-rater reliability agreement of the two investigators (MM and PRJA) for NOQAS was $0.47(95 \% \mathrm{CI}=0.293$ to 0.654$)$ according to Cohen's kappa.

\section{Populations under study}

Although the focus of the meta-analysis was the relation of aPL with renal transplant outside the setting of SLE six articles were "polluted" by the inclusion of patients with SLE: Vaidya et al. (14) $n=4(1.3 \%)$, Canaud et al (23) $n=17$ (18\%), Vaidya et al (25) $n=98(6 \%)$ Furmanzyck et al. (26) $n=3(8 \%)$, Serrano et al (27) $n=5(1.7 \%)$, Morales et al (29) $n=18$ (1.3\%); seven articles did not it make it clear whether SLE patients were included or not (9, $10,11,13,16,17,24)$ while the remaining did not include SLE patients $(12,15,18-20,22$, $28,30,31)$.

\section{Expression of antiphospholipid antibody positivity}

Most of the studies evaluated recipients positive for aPL $(9,10,12,13,16,17,19,22,24-26$, $28,29)$ whereas one study specifically evaluated recipients below the 40GPL/MPL cut-off for positivity but still low positive (31); fewer studies evaluated recipients positive for aPL as 
well as absolute aPL titres $(11,14,15,18,20,23,27)$. Where indicated and where possible we have shown cut-offs, average or median serum of aPL titres in Table 1B. Because the articles included in the meta-analysis expressed aPL in ways that made it difficult to extract or utilise data separately, we arbitrarily combined all aPL together, regardless of isotype and specificity, unless indicated in the relevant result section.

\section{CLINICAL DEFINITIONS}

\section{Allograft thrombosis}

The diagnosis of allograft thrombosis was consistently biopsy proven $(11,14,15,23,25-31)$ and occasionally supported by renal ultrasound or radionuclide scanning before biopsy (18).

\section{Non allograft thrombosis}

Two specific studies defined non allograft thrombosis as de novo coronary artery disease, cerebrovascular disease, peripheral vascular disease post renal allograft transplant $(17,22)$

\section{Allograft loss from all causes}

The definition of allograft loss yaried amongst studies: one study defined it as intra-renal thrombosis, rejection, haemorrhage (13), another study as resumption of chronic haemodialysis after transplant $(19,30)$ and a third as sudden death, vessel thrombosis, biopsy proven acute rejection, primary non-function $(28,29)$

\section{Allograft rejection}

Two studies defined/diagnosed acute (humoral and cellular) and delayed allograft rejection by renal biopsy $(19,30,31)$.

\section{Allograft malfunction}


Allograft malfunction was variably defined as transplant duration (10), worsening renal function (creatinine, proteinuria, eGFR) $(9,12,26,23)$ and requirement for transient haemodialysis sessions post allograft transplant $(19,29)$. These were combined together in our result section dealing with malfunction.

\section{META-ANALYSIS RESULTS}

\section{Allograft thrombosis}

Nine articles evaluated the relationship between different aPL and allograft thrombosis. They comprised 2106 aPL-ve and 1019 aPL+ve recipients for the effect size of this outcome [11, $14,15,23,26,28-31]$; the pooled prevalence of allograft thrombosis was significantly greater in aPL+ve than negative recipients $(10.4 \%$ vs $1.7 \%)$ with wide heterogeneity $\left(I^{2}=89.5 \%\right.$, $\mathrm{p}<0.0001$ ) (Figure 2A). Subgroup analysis after removal of three studies dealing with primary APS $[10,13,30]$ still yielded a significant result $(\mathrm{p}<0.0001)$ with decreased heterogeneity $\left(\mathrm{I}^{2}=71 \%, \mathrm{p}<0.004\right.$, graph not shown).

\section{Thrombotic microangiopathy}

Three articles evaluated the relationship between different aPL and thrombotic microangiopathy (TMA). The included 338 aPL-ve and 136 aPL+ve recipients for the effect size of this outcome $[11,14,23]$; the pooled prevalence of TMA was $10.2 \%$ in aPL+ve recipients whereas TMA did not occur in aPL-ve recipients with wide heterogeneity $\left(I^{2}=\right.$ $85 \%, \mathrm{p}<0.001)$ (Figure 2B). 


\section{Non-allograft thrombosis}

Six articles evaluated the relationship between different aPL and non-allograft thrombosis. They included 1690 aPL-ve and 885 aPL+ve recipients for the effect size of this outcome [10, $22,23,29,30,31]$; the pooled prevalence of non-allograft thrombosis was twice as greater in aPL+ve than-ve patients ( $8.8 \%$ vs $4.3 \%)$ with no heterogeneity (Figure $2 \mathrm{C})$. We then checked whether non-allograft thrombosis was more common in definite APS than in aPL+ve patients who never clotted; thee articles comprising 41APS recipients and 134 aPL+ve recipients were available for this effect size $(14,23,31)$; the pooled prevalence of nonallograft occlusion was 4 fold greater in APS than aPL+ve $(19.5 \%$ vs $4.4 \%)$ with no heterogeneity)(Figure 2D)

\section{Anticoagulant prevention of allograft thrombosis}

Five articles evaluated the efficacy of anticoagulation to prevent allograft thrombosis $(13,14$, $19,21,25)$. Of these, three evaluated the effect of oral anti vitamin K (AVK) anticoagulation compared to no anticoagulation $(14,19,25)$ : they comprised 40 aPL+ve patients, 16 receiving AVK and 24 not receiving AVK for the effect size of this outcome. The pooled prevalence of allograft thrombosis in non AVK recipients was $75 \%$ whereas none of the recipients on AVK developed thrombosis (no heterogeneity) (Figure 2E). Two studies (21, 25) compared the effect of AVK with that of low molecular heparin in 27 aPL+ve recipients, 14 of them receiving $\mathrm{AVK}$ and 13 receiving low molecular weight heparin for the effect size of this outcome. The pooled prevalence of allograft thrombosis in AVK recipients was lower than that of low molecular heparin recipients (14.2\% vs 30.7\%) (Figure 2F). One study compared the prophylactic effect of low molecular heparin on allograft thrombosis in aPL+ve and aPL-ve recipients (1/1 vs 0/9) but could not be considered for evaluation (14). 


\section{Allograft loss}

Nine studies evaluated $(11,13,14,15,25,26,28,29,30)$ the relationship between different aPL and allograft loss. Seven studies $(11,14,15,25,26,28,30)$ comprised 2083 aPL-ve and 547 aPL+ve recipients for the effect size of this outcome: the pooled prevalence of allograft loss was greater in aPL+ve recipients ( $18 \%$ vs $28 \%$ respectively) with elevated heterogeneity $\left(I^{2}=93 \%, \mathrm{p}<0.0001\right)(($ Figure $3 \mathrm{~A})$. Three studies $(13,26,30)$ comprised 855 recipients who did not lose their graft and 157 recipients who lost their graft for the effect size of this outcome: the pooled prevalence of aPL was significantly greater in recipients who lost their allograft compared to those who did not lose it (51\% vs $33 \%$ ) with no heterogeneity (Figure 3B).

\section{Allograft rejection}

Five studies evaluated the relationship between different aPL and allograft rejection: these include 2028 aPL-ve and 940 aPL+ve recipients for the effect size of this outcome [19, 2831]; the pooled prevalence of allograft rejection was relatively similar between the aPL+ve and negative groups (14.9\% vs $14.4 \%)$ (Figure 3C).

\section{Delayed graft function}

Four studies assessed the relationship between aPL and allograft rejection. These included 1882 aPL-ve and 839 aPL+ve recipients for the effect size of this outcome [19, 28-30). The pooled prevalence of allograft rejection greater was in the aPL+ve than negative recipients $(35.2 \%$ vs $22.4 \%)$ (Figure 3D) with moderate heterogeneity $\left(\mathrm{I}^{2}=60 \%, \mathrm{p}=0.05\right)$.

\section{Allograft malfunction and duration}

Three articles evaluated the relationship between different aPL and allograft malfunction. They comprised 152 aPL-ve and 57 aPL+ve recipients for the effect size of this outcome 
$[9,12,16]$; the pooled prevalence of allograft malfunction was not dissimilar in aPL-ve and positive recipients $(32.2 \%$ vs $40.3 \%$ ) (Figure 3E). Two articles from the same group evaluated the relationship between different aPL and allograft duration: these include 137 aPL negative and 128 positive recipients for the effect size of this outcome [19,29]; graft duration was much shorter in aPL+ve than aPL-ve recipients $(\mathrm{p}=0.001)($ Figure $3 \mathrm{~F})$.

\section{Estimated glomerular filtration rate at 1 year from allograft}

Three studies evaluated the glomerular filtration rate (GFR) at 1 year from allograft comprising 232 aPL negative and 148 aPL positive recipients for the effect size of this outcome $[23,26,31]$; the GFR was lower in aPL+ve than negative recipients $(p<0.0001)$ (Figure $3 \mathrm{G})$ with wide heterogeneity $\left(\mathrm{I}^{2} 71 \%, \mathrm{p}=0.03\right)$.

\section{Comparison of antiphospholipid antibody pre and post allograft}

Five articles evaluated the effect of renal transplant on $\operatorname{aPL}(17,18,20,22,24)$; in particular four investigated the de novo appearance of aPL or LA after renal transplant $(17,20,22,24)$, two studies both aPL and LA $(22,24)$ and three investigated the disappearance of aPL (18) and aPL and LA ( 22, 24) after renal transplant. The four studies evaluating a de-novo appearance of post-transplant aPL comprised 464 recipients; the pooled prevalence of aPL increased from $19 \%$ pre-transplant to $39 \%$ post-allograft $(\mathrm{p}<0.04)$ with wide heterogeneity though all studies favoured an increase (Figure 4A). Likewise the pooled prevalence of lupus anticoagulant increased from $5 \%$ pre-transplant to $38 \%$ post-allograft $(\mathrm{p}<0.0001)$ with low heterogeneity (Figure 4B).

The three studies evaluating the disappearance of pre-transplant aPL comprised 322 recipients in whom the pooled prevalence of aPL positivity dropped from $9.9 \%$ to nil $(\mathrm{p}=0.0001)$ with no heterogeneity (Figure 4C). The two studies evaluating the disappearance 
of pre-transplant lupus anticoagulant comprised 150 recipients in whom the pooled prevalence of positivity dropped from $6 \%$ to nil $(\mathrm{p}=0.002)$ with no heterogeneity (Figure 4D).

\section{DISCUSSION}

To gather a meaningful picture of the relation between aPL and renal allograft the studies included in the systematic review were grouped according to outcomes that for their nature dealt with the loss of the grafted kidney however defined: thrombosis, allograft loss proper, allograft rejection, allograft malfunction and duration with some information on vascular occlusion other than graft thrombosis.

Amongst the outcomes, the meta-analysis shows that aPL strongly associated with allograft thrombosis, association that remained such after a sub-group analysis that excluded the studies dealing with definite APS $(11,14)$, corroborating the fact that a single aPL positivity in the peri-transplant period may bear intra-renal thrombogenic potential. This is an interesting point as the articles dealing with APS studies $(11,14,23)$ included recipients with aPL higher than the thrombogenic IgGaCL 40GPL threshold (32); indeed, one study showed that with an aCL cut-off at 15 GPL/MPL, aPL titre did not predict poor outcomes, though increasing the aCL cut-off at 50 GPL/MPL a small proportion of allograft recipients $(n=2 / 5)$ not on oral anticoagulation underwent intra-renal thrombosis within the first month from transplant (19). Moreover a recent article present in our meta-analysis performed a study including recipients below the 40GPL/MPL cut-off: indeed the authors did not report any intra or extra graft thrombosis, rather declining graft function at one 1 year from transplant that on biopsy proved to be mostly tubular atrophy, still an ischemic complication (31). With this in mind we investigated whether extra-renal thrombosis was more common in APS groups than in isolated aPL and we found that non-allograft occlusion was four times more common in APS. Unfortunately we lack information on thrombogenic thresholds for IgG and 
IgA $a \beta_{2}$ GPI and most of the remaining studies expressed their aPL in percent of positive patients with variable cut offs, a fact that limits our understanding not only on the role of aPL in renal allograft thrombosis, but also on the development of vascular occlusions in districts other than the kidney, as the meta-analysis revealed.

Nevertheless, during renal transplant, the combination of surgical stress (33) and ischaemia-reperfusion injury $(34,35)$ leads to oxidative stress $(36)$; this promotes intra-graft endothelial Toll-like receptor-4 activation and apoptosis $(34,35)$ that ultimately plays a major role in the development of intra-renal thrombosis; given that oxidative stress and Toll-like receptor-4 are involved in APS thrombogenesis $(37,38)$ the presence of aPL in allograft recipients may add to the risk of intra-renal thrombosis. Despite being a detrimental complication of kidney transplant, aPL mediated allograft thrombosis seems also preventable: in fact, post-transplant initiation of AVK protected the allograft from the thrombogenic potential of aPL though this encouraging data came from three studies only $(11,14,25)$.

With regards to allograft loss from any cause, there was a significant relation with aPL and despite the wide heterogeneity all studies bar one favoured the relationship; this was supported by pooled data from three studies showing a greater prevalence of aPL in recipients who lost their allograft. On the other hand the pooled data on allograft rejection are against an involvement of aPL in this complication that is supported by different cellular and humoral immunity pathways (39). Likewise the pooled data on allograft malfunction did not favour a link with aPL, though aPL positive recipients displayed a shorter graft duration, and although the authors of these studies were investigating atherosclerotic related event in their allograft recipients, they did not pursue kidney biopsies to ascertain the causes of reduced allograft survival (17). 
One behaviour of aPL in the renal transplant setting is intriguing: in some studies preallograft aPL disappeared post-allograft, while de novo aPL appeared post-allograft and the pooled data were significant both ways. It is possible that removal of the damaged kidney eliminates a chronic auto-antigenic stimulus with a likely fall in autoantibody production including aPL. Similarly the decrease of $\operatorname{IgA} a \beta_{2}$ GPI post-transplant (27) may reflect the removal of an active intra-renal site of IgA production such as mesangial cells (40) though there is no evidence for such synthesis hence a drop for $\operatorname{IgG}$ and/or $\operatorname{IgM}$.

With regards to the de novo appearance of aPL post allograft, sometimes for a short period (20), a surge in oxidative stress induced by the new kidney (36) over a given background (41) may represent an added stimulus to the rapid generation of auto-antibodies against oxidated lipids from (42) by auto-reactive memory B cells harbouring also aPL in their repertoire; among these, the IgM isotype represents a natural auto-antibodies with a protective role still able to behave as lupus anticoagulant (20) that may disappear, while others, clonally selected, may persist for a longer time (43).

The FcRn (neonatal Fc receptor) is a class I MHC molecule expressed amongst others in podocytes, renal proximal tubule cells and vascular endothelium of the kidney that acts as a specific and saturable receptor for IgGs, regulating their transport and recycling, protecting them from catabolism (44). In kidney cell lines IgG show a bidirectional transport across primary human renal proximal tubular epithelium (45). Excess IgG filtered through the basal glomerular membrane is either reabsorbed by podocyte FcRn that prevent thus the deposition of immune complexes leading to glomerular disease (44) either reabsorbed downstream by the FcRn in the proximal tubules (46). However, upon kidney transplantation from FcRn wild type to FcRn-deficient mice, albumin was salvaged from urinary loss, but IgG secretion was rather promoted by FcRn restoration (47). That renal allografts in aPL recipients were followed either by the abrogation or by an increase of aPL titers is in line with the 
complexities concerning the net balance of the compound IgG fluxes mediated by FcRn in renal vascular endothelium, podocytes and proximal tubular epithelial cells. It is likely that, in patients receiving renal allografts, the equilibrium between $\mathrm{IgG}$ clearance and reabsorption might be influenced by: a) the degree of compromise of the FcRn-mediated IgG salvage pathway in the removed kidneys; b) the degree of restoration by the allografts; c) the presence and intensity of a rejection responses towards FcRn (which is fundamentally a class I MHC molecule) in transplanted kidneys. Although the meta-analysis refuted the participation of aPL in allograft rejection, one study reported the de novo appearance of PL in coincidence with rejection (22), an occurrence that does not exclude the arguments cited above.

Limitations of the meta-analysis are: 1) limited number of studies within individual meta-analysis; indeed the largest analysis (Figure 2A) was carried out on only nine studies that precluded a proper estimation of publication bias as at least ten are required for the proper performance of a funnel plot (8) though we tried to redress the balance by running also a grey literature search that was poorly informative; 2) variability in study sizes; 3) different endpoints and different subtypes of aPL measured, hence the need to pool together $\operatorname{IgG}$ and IgM isotypes; 4) expression of data as frequency of aPL positive recipients rather than average antibody titres in many papers; 5) minor "pollution" by the inclusion of SLE recipients in few studies though the numbers are small and unlikely to affect the significance of the meta-analysis; 6) use of anti-platetet and anti-vitamin $\mathrm{K}$ agents in the peri-transplant periods that could not be accounted for in some studies because the data was not extractable. A perceived limitation of the meta-analysis might be the use of additional treatment modalities such as plasma exchange, intravenous immunoglobulins or anti-CD20 that may affect aPL related outcomes, but these were not employed by any of the included studies. 


\section{Conclusion}

There is a strong link between aPL and different renal allograft outcomes including intra and extra-renal thrombosis, allograft loss proper and allograft duration but not with allograft rejection. AVK anticoagulants are effective in preventing allograft thrombosis though this could be offset by an increased risk of bleeding in the perioperative period. The limited numbers of papers reporting data on LA and the expression of data as percentage of recipients positive for aPL rather than aPL titres in many studies precludes a wider debate on the role of aPL in renal transplant.

\section{References}

[1] Cervera R. Antiphospholipid syndrome. Thromb Res 2017; 151 Suppl 1: S43-S47

[2] Marcantoni C, Emmanuele C, Scolari F. Renal involvement in primary antiphospholipid syndrome. J Nephrol 2016; 29: 507-515

[3] Canaud G, Legendre C. Kidney allograft: a target for systemic disease. Presse Med 2012; 41 (3 Pt 1): 311-317

[4]Shamseer L, Moher D, Clarke M, Ghersi D, Liberati A, Petticrew M et al. PRISMA-P Group. Preferred reporting items for systematic review and meta-analysis protocols (PRISMA-P) 2015: elaboration and explanation. BMJ 2015; 349: g7647

[5] Wells GA, Shea B, O'Connell D, Peterson J, Welch V, Losos M et al. Ottawa Hospital Research Institute. The Newcastle-Ottawa Scale (NOS) for assessing the quality of non randomized studies in meta-analysis. Available from URL: www.ohri.ca/programs/ clinical_epidemiology/oxford.htm

[6] Bradburn MJ, Deeks JJ, Berlin JA, Russell Localio A. Much ado about nothing: a comparison of the performance of meta-analytical methods with rare events. Stat Med 2007; 26: $53-77$

[7] Tang JL, Liu JL. Misleading funnel plot for detection of bias in meta-analysis. Clin Epidemiol 2000; 253: 477-484

[8] Lau J, Ioannidis JPA, Terrin N, Schmid CH, Olkin I. The case of the misleading funnel plot. Br Med J 2006; 333: 597-600 
[9] Ramírez E, Serrano A, García F, Alfaro FJ, Pérez V, Paz-Artal E et al. Prospective study on autoantibodies against apolipoprotein $\mathrm{H}$ (beta2GPI) in several clinical parameters from patients with terminal renal failure and functioning renal transplants. Transplant Proc 2009; 41: 2370

[10] Ducloux D, Pellet E, Chalopin JM. Prevalence and clinical significance of antiphospholipid antibodies in renal transplant recipients. Transplant Proc 1997; 29: 24002041

[11] Vaidya S, Wang C, Gugliuzza K, Fish JC. Antiphospholipid antibody syndrome and posttransplant renal thrombosis. Transplant Proc 1999; 31: 230-233

[12] Grandtnerová B, Gregová H, Mociková H, Zacharová M, Zárnovicanová M. Anticardiolipin antibodies after kidney transplantation in patients without connective tissue disease. Transplant Proc 1999; 31: 228.

[13] Wagenknecht DR, Fastenau DR, Torry RJ, Becker DG, LeFor WM, Carter CB et al. Risk of early renal allograft failure is increased for patients with antiphospholipid antibodies. Transplant International 2000; 13 Suppl 1:S78-81.

[14] Vaidya S, Sellers R, Kimball P, Shanahan T, Gitomer J, Gugliuzza K at al. Frequency, potential risk and therapeutic intervention in end-stage renal disease patients with antiphospholipid antibody syndrome: a multicenter study. Transplantation 2000; 69: 13481352.

[15] Friedman GS, Meier-Kriesche HU, Kaplan B, Mathis AS, Bonomini L, Shah N et al. Hypercoagulable states in renal transplant candidates: impact of anticoagulation upon incidence of renal allograft thrombosis. Transplantation 2001; 72: 1073

[16] McIntyre JA, Wagenknecht DR. Antiphospholipid antibodies and renal transplantation: a risk assessment. Lupus 2003; 12: 555-559

[17] Ducloux D, Bourrinet E, Motte G, Chalopin J-M. Antiphospholipid antibodies as a risk factor for atherosclerotic events in renal transplant recipients. Kidney international 2003; 64: 1065

[18] Nampoory RN, Das C, Johny V, Al-Hilali N, Abraham M, Easow S et al. Hypercoagulability, a serious problem in patients with ESRD on maintenance hemodialysis, and its correction after kidney transplantation. American Journal Kidney Diseases 2003; 42: 797

[19] Forman P, Lin J, Pascual M, Denton D, Tolkoff-Rubin N. Significance of anticardiolipin antibodies on short and long term allograft survival and function following kidney transplantation. American Journal of Transplantation 2004; 4: 1786

[20] Nybo M, Dieperink H, Kristensen SR. Prolonged aPTT after kidney transplantation due to transient lupus anticoagulants. Nephrology Dialysis Transplantation 2006; 21: 1060-1065 
[21] Rubenwolf P, Lopau K, Gerharz EW, Heidbreder E, Riedmiller H. Antiphospholipid antibody syndrome: a priori a contraindication to kidney transplantation? Aktuelle Urol 2007; 38: $132-136$.

[22] Fernandez-Fresnedo G, Lopez-Hoyos M, Segundo DS, Crespo J, Ruiz JC, De ALM et al. Antiphospholipid antibodies after renal transplantation and cardiovascular disease. Clinical Transplantation 2008; 22: 567-571

[23] Canaud G, Bienaimé F, Noël LH, Royal V, Alyanakian MA, Dautzenberg MD et al. Severe vascular lesions and poor functional outcome in kidney transplant recipients with lupus anticoagulant antibodies. American Journal Transplantation 2010; 10: 2051

[24] Ghisdal L, Broeders N, Wissing KM, Mena JM, Lemy A, Wijns W et al. Thrombophilic factors in Stage $\mathrm{V}$ chronic kidney disease patients are largely corrected by renal transplantation. Nephrology, Dialysis, Transplantation 2011; 26: 2700

[25] Vaidya S. Ten-yr renal allograft survival of patients with antiphospholipid antibody syndrome. Clinical Transplantation 2012; 26: 853-856

[26] Furmańczyk-Zawiska A, Bączkowska T, Sadowska A, Szmidt J, Chmura A, Durlik M. Antiphospholipid antibodies in renal allograft recipients. Transplantation proceedings 2013; 45: 1655

[27] Serrano M, Martínez-Flores JA, Castro MJ, García F, Lora D, Pérez D et al. Renal transplantation dramatically reduces IgA anti-beta-2-glycoprotein I antibodies in patients with end stage renal disease. Journal Immunology Research 2014; 2014: 641962

[28] Morales M, Martinez-Flores JA, Serrano M, Castro MJ, Alfaro FJ, García F et al. Association of early kidney allograft failure with preformed IgA antibodies to $\beta 2$ glycoprotein I. Journal American, Society Nephrology 2015; 26: 735

[29] Morales JM, Serrano M, Martinez-Flores JA, Perez D, Castro MJ, Sanchez E et al. The Presence of Pretransplant Antiphospholipid Antibodies IgA Anti-beta-2-Glycoprotein I as a Predictor of Graft Thrombosis After Renal Transplantation. Transplantation 2016.

[30] Morales JM, Serrano M, Martinez-Flores JA, Gainza FJ, Marcen R, Arias M et al. Pretransplant IgA-Anti-Beta 2 Glycoprotein I Antibodies As a Predictor of Early Graft Thrombosis after Renal Transplantation in the Clinical Practice: A Multicenter and Prospective Study. Front Immunol 2018; 9:468. doi: 10.3389/fimmu.2018.00468. eCollection 2018.

[31] Gauthier M, Canoui-Poitrine F, Guéry E, Desvaux D, Hue S, Canaud G et al. Anticardiolipin antibodies and 12-month graft function in kidney transplant recipients: a prognosis cohort survey. Nephrol Dial Transplant 2018. doi: 10.1093/ndt/gfx353. [Epub ahead of print]

[32] Finazzi G, Brancaccio V, Moia M, Ciaverella N, Mazzucconi MG, Schinco PC et al. Natural history and risk factors for thrombosis in 360 patients with antiphospholipid 
antibodies: a four-year prospective study from the Italian Registry. Am J Med 1996; 100: $530-536$

[33] Raschi E, Chighizola CB, Grossi C, Ronda N, Gatti R, Meroni PL et al. $\beta 2$-glycoprotein I, lipopolysaccharide and endothelial TLR4: three players in the two hit theory for antiphospholipid-mediated thrombosis. J Autoimmun 2014; 55: 42-50

[34] Kasimsetty SG, McKay DB. Ischemia as a factor affecting innate immune responses in kidney transplantation. Curr Opin Nephrol Hypertens 2016; 25: 3-11

[35] Salvadori M, Rosso G, Bertoni E. Update on ischemia-reperfusion injury in kidney transplantation: Pathogenesis and treatment. World J Transplant 2015; 5: 52-67

[36] Tabriziani H, Lipkowitz MS, Vuong N. Chronic kidney disease, kidney transplantation and oxidative stress: a new look to successful kidney transplantation. Clin Kidney J 2018; 11 : $130-135$

[37] Ames PR, Tommasino C, Alves J, Morrow JD, Iannaccone L, Fossati G et al. Antioxidant susceptibility of pathogenic pathways in subjects with antiphospholipid antibodies: a pilot study. Lupus 2000; 9: 688-695

[38] Laplante P, Fuentes R, Salem D, Subang R, Gillis MA, Hachem A et al. Antiphospholipid antibody-mediated effects in an arterial model of thrombosis are dependent on Toll-like receptor 4. Lupus 2016; 25: 162-176

[39] Goldberg RJ, Weng FL, Kandula P. Acute and Chronic Allograft Dysfunction in Kidney Transplant Recipients. Med Clin North Am 2016; 100: 487-503

[40] Deng H, Ma J, Jing Z, Deng Z, Liang Y, Liu AL et al. Expression of immunoglobulin A in human mesangial cells and its effects on cell apoptosis and adhesion. Mol Med Rep 2018; 17: $5272-5282$

[41] Duni A, Liakopoulos V, Rapsomanikis KP, Dounousi E. Chronic Kidney Disease and Disproportionally Increased Cardiovascular Damage: Does Oxidative Stress Explain the Burden? Oxid Med Cell Longev 2017; 2017

[42] Carter MJ, Mitchell RM, Meyer Sauteur PM, Kelly DF, Trück J. The AntibodySecreting Cell Response to Infection: Kinetics and Clinical Applications. Front Immunol 2017; 8:630

[43] Lieby P, Soley A, Knapp AM, Cerutti M, Freyssinet JM, Pasquali JL et al. Memory B cells producing somatically mutated antiphospholipid antibodies are present in healthy individuals. Blood 2003; 102: 2459-2465

[44] Akilesh S, Huber TB, Wu H et al. Podocytes use FcRn to clear IgG from the glomerular basement membrane. Proc Natl Acad Sci USA 2008; 105: 967-972 
[45] Kobayashi N, Suzuki Y, Tsuge T, Okumura K, Ra C, Tomino Y. FcRn-mediated transcytosis of immunoglobulin $\mathrm{G}$ in human renal proximal tubular epithelial cells. Am $\mathrm{J}$ Physiol Renal Physiol 2002: 282: F358-365

[46] Haymann JP, Levraud JP, Bouet S, et al. Characterization and localization of the neonatal Fc receptor in adult human kidney. J Am Soc Nephrol 2000: 11: 632-639

[47] Sarav M, Wang Y, Hack BK, Chang A, Jensen M, Bao L, et al. Renal FcRn reclaims albumin but facilitates elimination of IgG. J Am Soc Nephrol 2009 20: 1941-1952

Conflict of interest: none of the authors have any conflict of interest to declare

\section{Legend to Figures}

Figure 1. Summary of the literature search according to the Prisma flow-chart. The box provides a detail of the full text excluded.

Figure 2. Forest plots of the effect size of: A) allograft thrombosis; B) thrombotic microangiopathy; C) non-allograft thrombosis; D) non allograft thrombosis between aPL and APS; E) oral anticoagulation in allograft thrombosis; F) oral anticoagulation versus low molecular heparin in allograft thrombosis, after renal allograft. Abbreviations. aPL: antiphospholipid antibodies; -ve: negative; +ve positive; APS: primary antiphopsholid syndrome.

Figure 3. Forest plots of the effect size of: A) allograft loss, B) aPL in allograft loss; C) allograft ejection; D) delayed graft function; E) allograft malfunction; F) graft duration; G) estimated glomerular filtration rate, after renal allograft. Abbreviations. aPL: antiphospholipid antibodies; -ve. negative; +ve positive.

Figure 4. Forest plots of the effect size of: A) increase in aPL; B) increase in lupus anticoagulant; C) decrease in lupus anticoagulant after renal allograft. 
Allograft thrombosis post renal transplant

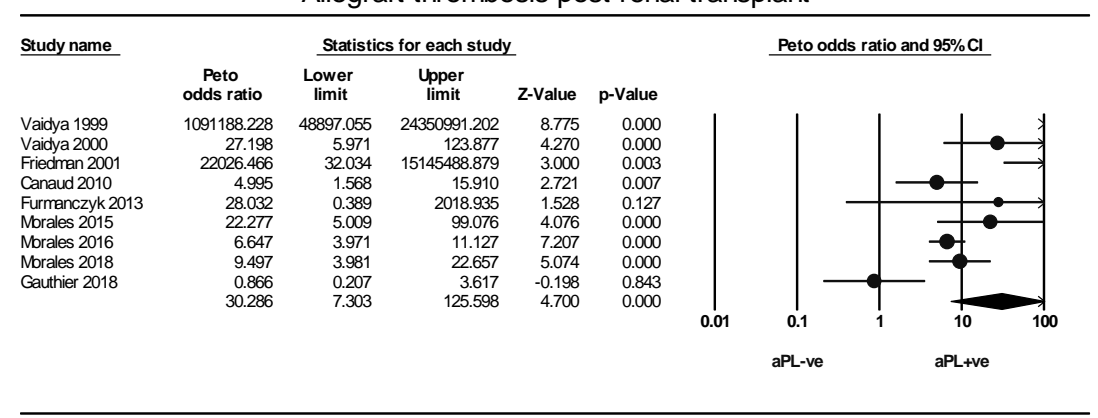

Overall: I squared $89.5 \%, p<0.0001$

Figure 2A

Thrombotic microangiopathy after renal transplant

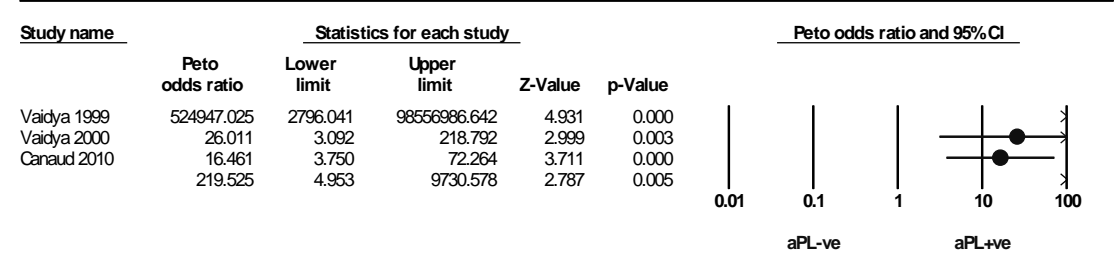

Overall: I squared $85 \%, p=0.001$

Figure 2B

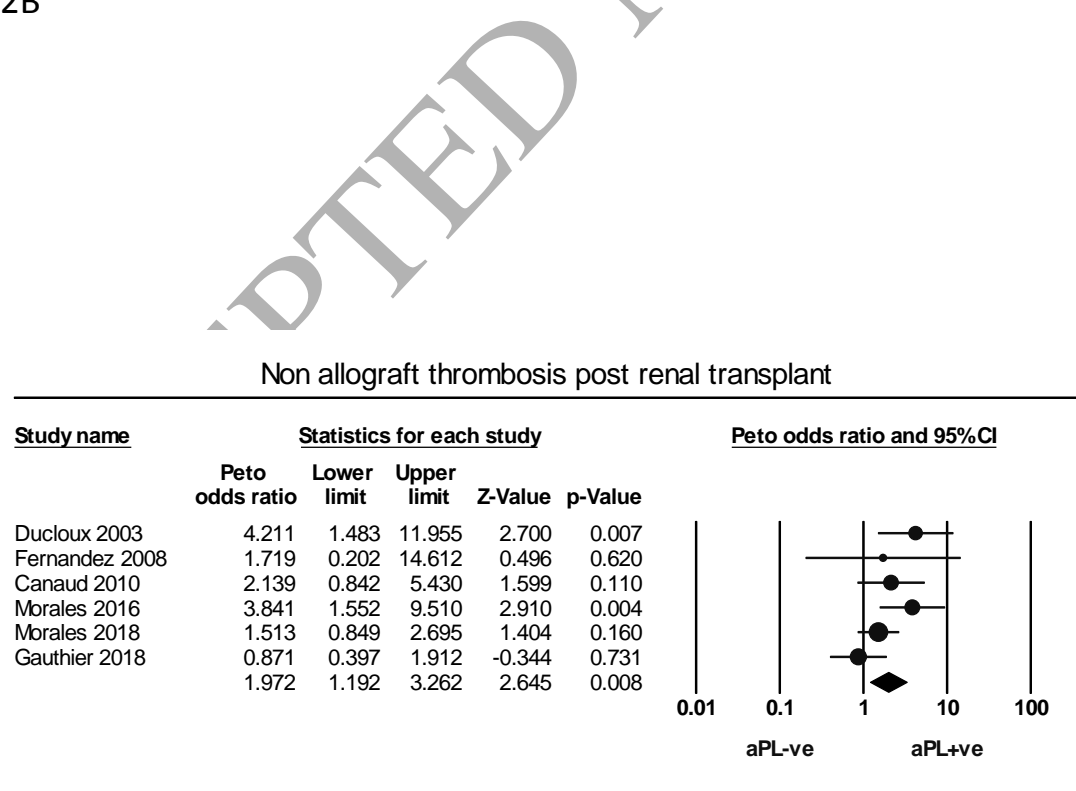

Overall: I squared $44 \%, p=0.1$

Figure 2C 
Non allograft thrombosis in APS and $\mathrm{APL}+$ ve post renal transplant

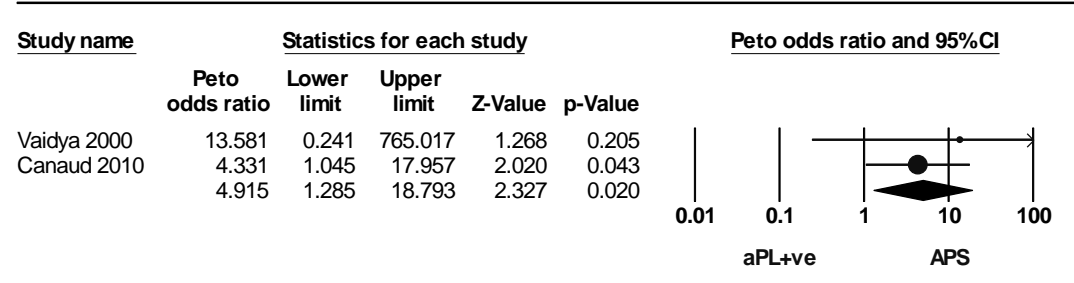

Overall: I squared $0 \%$

Figure 2D

Allograft thrombosis and oral anticoagulation

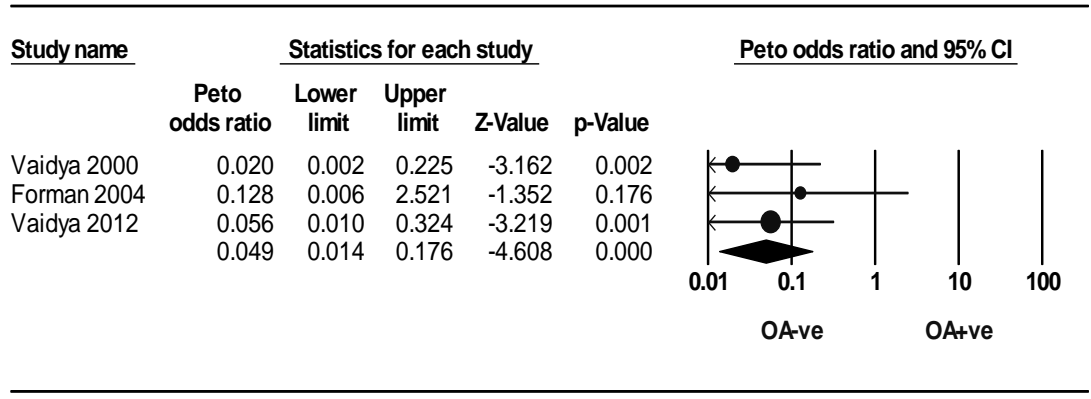

Overall: I squared $0 \%$

Figure 2E

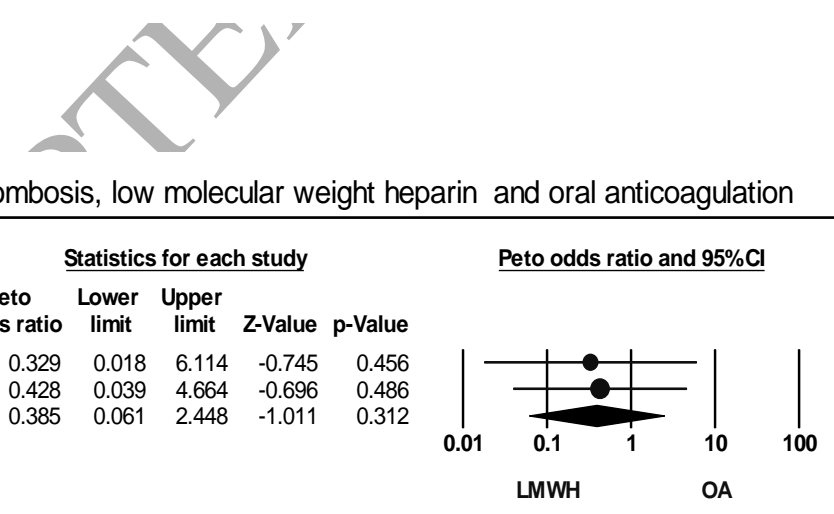

Overall: I squared $0 \%$

Figure $2 \mathrm{~F}$ 
Alfograft loss after renal transplant

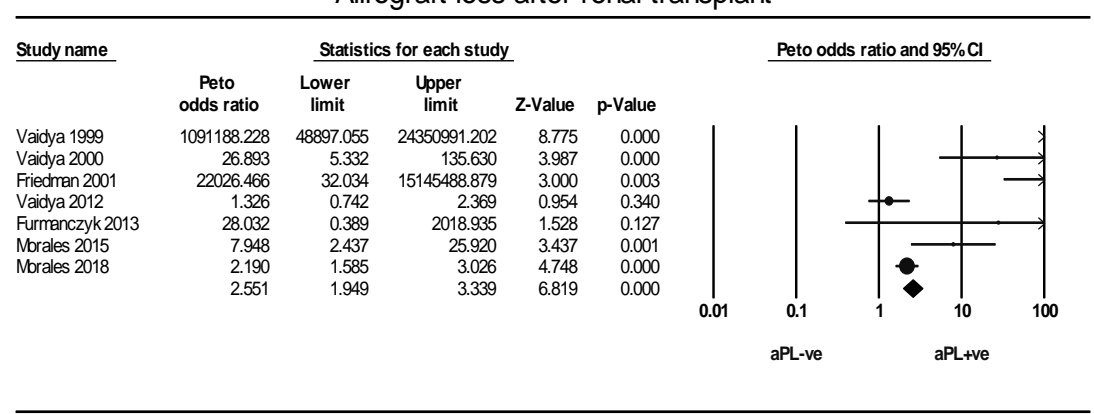

Overall: I squared $93 \%, p<0.0001$

Figure $3 \mathrm{~A}$

Antiphospholipid antibodies in allograft loss after renal transplant

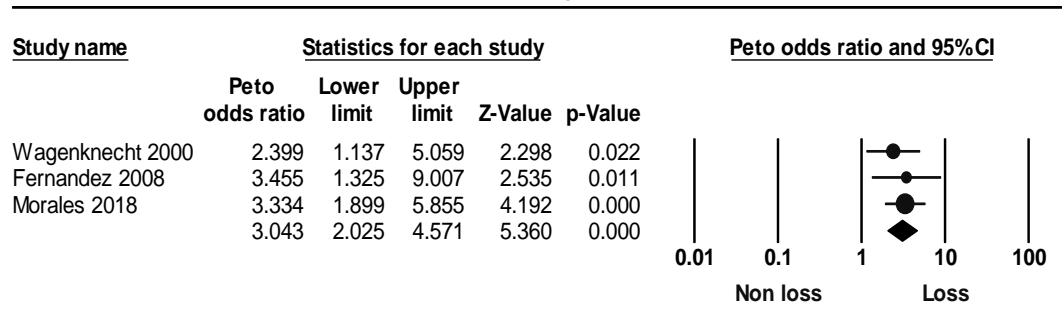

Overall: I squared 0\%

Figure 3B

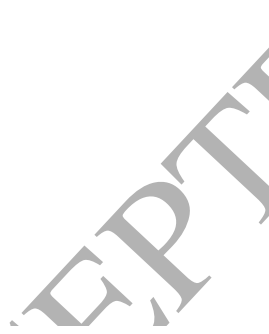

Allograft rejection after renal transplant

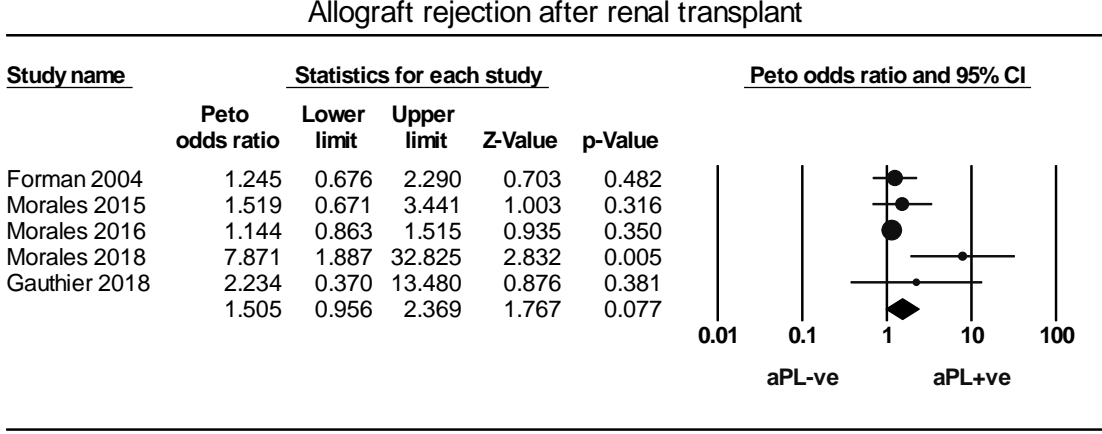

Overall: I squared $85 \%, p=0.001$

Figure $3 \mathrm{C}$ 
Delayed graft function after renal transplant

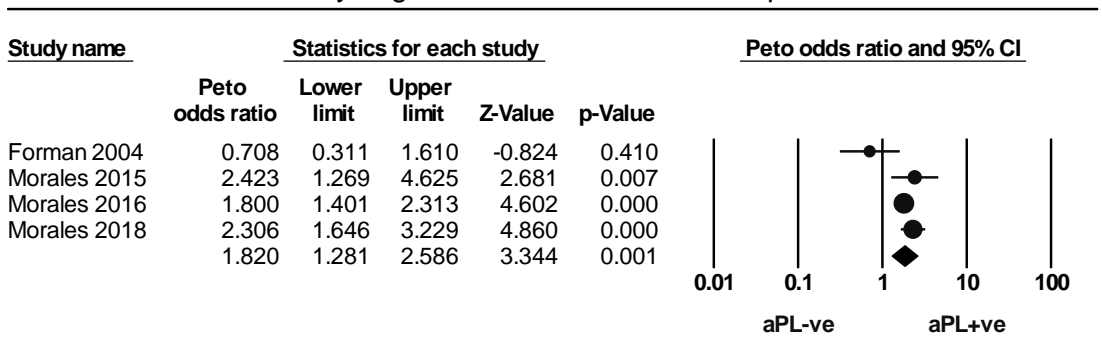

Overall: I squared $60 \%, p=0.05$

Figure 3D

Allograft malfunction after renal transplant

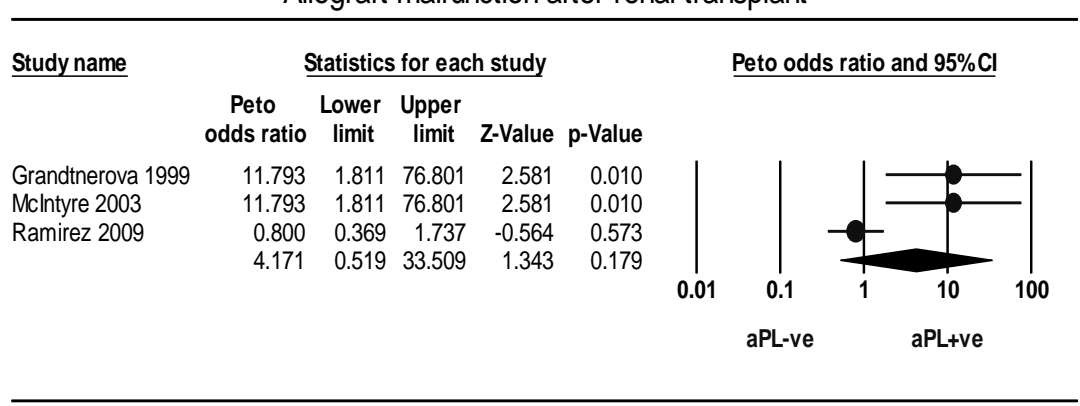

Overall: I squared $83 \%, p=0.003$

Figure 3E

Graft duration after renal transplant

\begin{tabular}{|c|c|c|c|c|c|c|c|c|c|c|c|}
\hline \multirow[t]{2}{*}{ Study name } & \multicolumn{7}{|c|}{ Statistics for each study } & & \multicolumn{3}{|c|}{ Std diff in means and $95 \% \mathrm{Cl}$} \\
\hline & $\begin{array}{c}\text { Std diff } \\
\text { in means }\end{array}$ & $\begin{array}{l}\text { Standard } \\
\text { error }\end{array}$ & Variance & $\begin{array}{l}\text { Lower } \\
\text { limit }\end{array}$ & $\begin{array}{c}\text { Upper } \\
\text { limit }\end{array}$ & Z-Value & $\mathrm{p}$-Value & & & & \\
\hline $\begin{array}{l}\text { Docloux } 1997 \\
\text { Docloux } 2003\end{array}$ & $\begin{array}{l}0.465 \\
0.404 \\
0.431\end{array}$ & $\begin{array}{l}0.195 \\
0.172 \\
0.129\end{array}$ & $\begin{array}{l}0.038 \\
0.030 \\
0.017\end{array}$ & $\begin{array}{l}0.083 \\
0.066 \\
0.178\end{array}$ & $\begin{array}{l}0.846 \\
0.742 \\
0.684\end{array}$ & $\begin{array}{l}2.385 \\
2.344 \\
3.336\end{array}$ & $\begin{array}{l}0.017 \\
0.019 \\
0.001\end{array}$ & -2.00 & -1.00 & $0.00 \quad 1.00$ & 2.00 \\
\hline
\end{tabular}

Overall: I squared $0 \%$

Figure $3 \mathrm{~F}$ 
Estimated GFR at 1 year from renal transplant

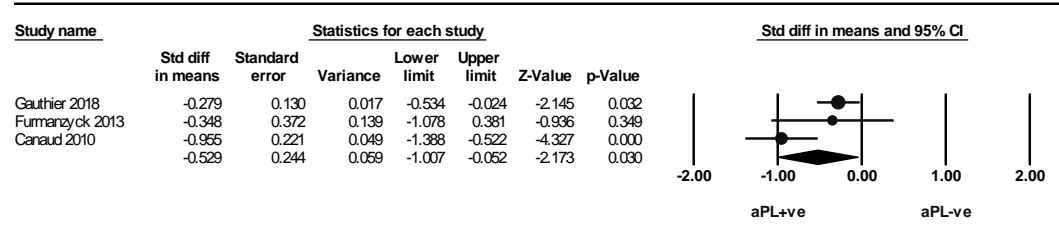

Overall: I squared $71 \%, p=0.03$

Figure 3G

Increase in antiphospholipid antibodies post renal allograft

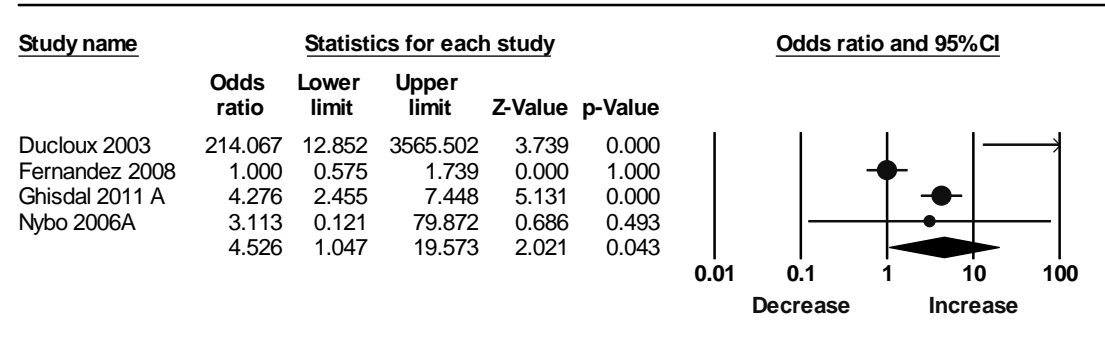

Overall: I squared $87 \%, p<0.0001$

Figure 4A

Increase in lupus antiicoagulant post renal allograft

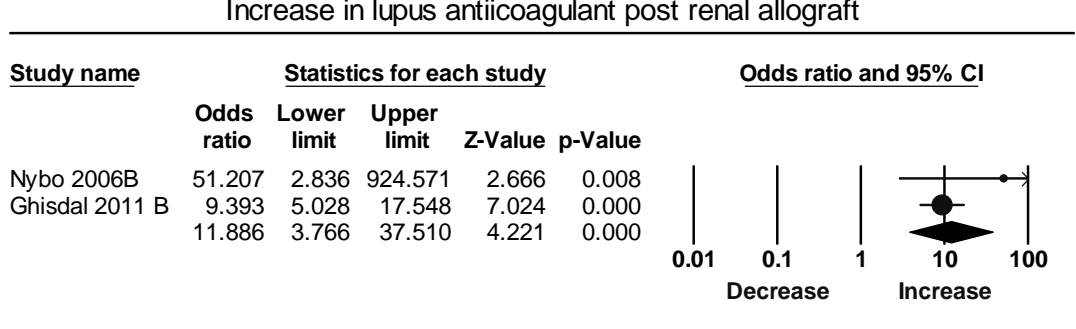

Overall: I squared $20 \%, p=0.2$

Figure 4B 
Decrease in antiphospholipid antibodies post renal allograft

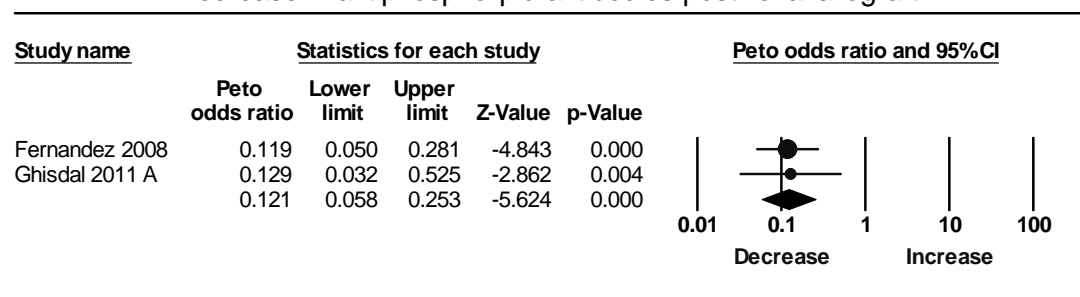

Overall: I squared $0 \%$

Figure $4 \mathrm{C}$

Decrease in lupus anticoagulant post renal allograft

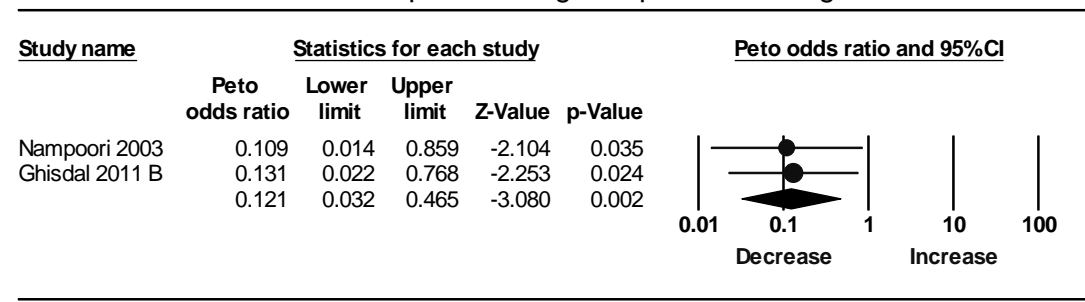

Overall: I squared $0 \%$

Figure 4D 
Table 1. Demographics of the studies included in the meta-analysis

\begin{tabular}{|c|c|c|c|c|c|c|c|c|c|c|c|c|c|c|c|c|c|c|c|}
\hline \multirow[b]{3}{*}{$\begin{array}{l}\text { Cohort } \\
\text { Studies }\end{array}$} & \multicolumn{9}{|c|}{ aPL+ve } & \multicolumn{9}{|c|}{ aPL-ve } & \multirow{3}{*}{$\begin{array}{l}\mathbf{N} \\
\text { OS }\end{array}$} \\
\hline & & & & \multicolumn{6}{|c|}{ ALLOGRAFT OUTCOMES } & & & & \multicolumn{6}{|c|}{ ALLOGRAFT OUTCOMES } & \\
\hline & $\begin{array}{l}\mathbf{N} \\
\mathbf{0} \\
\end{array}$ & $\begin{array}{c}\text { M/ } \\
\mathbf{F}\end{array}$ & Age & $\begin{array}{l}\mathbf{H} \\
\mathbf{R} \\
\end{array}$ & $\begin{array}{c}\text { NAT } \\
\text { HR }\end{array}$ & $\begin{array}{l}\text { LO } \\
\text { SS }\end{array}$ & $\begin{array}{c}\text { D } \\
\text { GF }\end{array}$ & $\begin{array}{l}\mathbf{A} \\
\mathbf{R}\end{array}$ & $\begin{array}{l}\text { M } \\
\text { FN }\end{array}$ & No & $\mathbf{M} / \mathbf{F}$ & Age & $\begin{array}{l}\mathbf{H} \\
\mathbf{R} \\
\end{array}$ & $\begin{array}{c}\text { NAT } \\
\text { HR } \\
\end{array}$ & $\begin{array}{l}\text { LO } \\
\text { SS }\end{array}$ & $\begin{array}{c}\text { D } \\
\text { GF }\end{array}$ & $\begin{array}{l}\mathbf{A} \\
\mathbf{R} \\
\end{array}$ & $\begin{array}{l}\mathrm{M} \\
\mathrm{FN}\end{array}$ & \\
\hline $\begin{array}{l}\text { Ducloux } \\
1997 \\
\end{array}$ & $\begin{array}{l}4 \\
1 \\
\end{array}$ & & 48 & & & & & & & 79 & & 47 & & & & & & & 7 \\
\hline Vaidya 1999 & 6 & & & 6 & & 6 & & & & 72 & & & 0 & & 0 & & & & 6 \\
\hline $\begin{array}{l}\text { Grandtnero } \\
\text { va } 1999\end{array}$ & $\begin{array}{l}1 \\
1\end{array}$ & & 43 & & & & & & 6 & 9 & & $\begin{array}{c}47 . \\
5\end{array}$ & & & & & & 0 & 5 \\
\hline $\begin{array}{l}\text { Wagenknec } \\
\text { ht } 2000\end{array}$ & $\begin{array}{l}3 \\
2 \\
\end{array}$ & & & & & 56 & & & & 19 & & & & & 54 & & & & 5 \\
\hline Vaidya 2000 & $\begin{array}{l}9 \\
3 \\
\end{array}$ & & & 7 & & 7 & & & & $\begin{array}{c}20 \\
7\end{array}$ & & & 0 & & & & & & 5 \\
\hline $\begin{array}{l}\text { Friedman } \\
2001\end{array}$ & 1 & & & 1 & & 1 & & & & 9 & & & 0 & & 0 & & & & 4 \\
\hline $\begin{array}{l}\text { Ducloux } \\
2003 \\
\end{array}$ & $\begin{array}{l}3 \\
7 \\
\end{array}$ & & & & 13 & & & & & 47 & & & & 5 & & & & & 7 \\
\hline $\begin{array}{l}\text { Nampoori } \\
2003 \\
\end{array}$ & 4 & & $\begin{array}{c}36 \pm \\
15 \\
\end{array}$ & & & & & & & 0 & & & & & & & & & 7 \\
\hline $\begin{array}{l}\text { Mclntyre } \\
2003 \\
\end{array}$ & $\begin{array}{l}1 \\
1 \\
\end{array}$ & & & & & & & & 6 & 9 & & & & & & & & 0 & 5 \\
\hline $\begin{array}{l}\text { Forman } \\
2004 \\
\end{array}$ & $\begin{array}{l}6 \\
1 \\
\end{array}$ & $\begin{array}{c}36 / \\
25 \\
\end{array}$ & $\begin{array}{c}44 \pm \\
15 \\
\end{array}$ & & & & 6 & $\begin{array}{l}2 \\
0 \\
\end{array}$ & & $\begin{array}{c}27 \\
6 \\
\end{array}$ & $\begin{array}{c}169 / \\
107 \\
\end{array}$ & $\begin{array}{c}45 \pm \\
13 \\
\end{array}$ & & & & 38 & $\begin{array}{l}7 \\
8 \\
\end{array}$ & 0 & 8 \\
\hline Nybo 2006 & $\begin{array}{l}1 \\
4 \\
\end{array}$ & & $\begin{array}{c}43 \pm \\
17 \\
\end{array}$ & & & & & & & 0 & & & & & & & & & 5 \\
\hline $\begin{array}{l}\text { Fernandez } \\
2008 \\
\end{array}$ & $\begin{array}{l}2 \\
1 \\
\end{array}$ & & $\begin{array}{c}45 \pm \\
11 \\
\end{array}$ & & 3 & & & & 46 & 12 & & & & 1 & & & & & 6 \\
\hline $\begin{array}{l}\text { Ramirez } \\
2009 \\
\end{array}$ & $\begin{array}{l}3 \\
5 \\
\end{array}$ & & $\begin{array}{c}55 \pm \\
11 \\
\end{array}$ & & & & & & 11 & $\begin{array}{c}13 \\
4 \\
\end{array}$ & & & & & & & & 49 & 4 \\
\hline $\begin{array}{l}\text { Canaud } \\
2010 \\
\end{array}$ & $\begin{array}{l}3 \\
7 \\
\end{array}$ & & $\begin{array}{c}55 \pm \\
12 \\
\end{array}$ & 10 & 22 & & & & & 59 & & $\begin{array}{c}54 \pm \\
11 \\
\end{array}$ & 4 & 12 & & 8 & & & 8 \\
\hline $\begin{array}{l}\text { Ghisdal } \\
2011\end{array}$ & $\begin{array}{l}1 \\
4 \\
4 \\
\end{array}$ & & & & & & & & & $\begin{array}{c}11 \\
2 \\
\end{array}$ & & & & & & & & & 6 \\
\hline Vaidya 2012 & $\begin{array}{l}6 \\
7 \\
\end{array}$ & & & & & 19 & & & & $\begin{array}{l}11 \\
56 \\
\end{array}$ & & & & & $\begin{array}{c}26 \\
9 \\
\end{array}$ & $\begin{array}{c}26 \\
9 \\
\end{array}$ & & & 6 \\
\hline $\begin{array}{l}\text { Furmanczyk } \\
2013\end{array}$ & 3 & & & 1 & & 1 & & & & 7 & & & 0 & & 0 & & & & 6 \\
\hline $\begin{array}{l}\text { Serrano } \\
2014\end{array}$ & $\begin{array}{l}2 \\
8 \\
8 \\
\end{array}$ & & & & & & & & & $\begin{array}{c}28 \\
8\end{array}$ & & & & & & & & & 6 \\
\hline $\begin{array}{l}\text { Morales } \\
2015 \\
\end{array}$ & $\begin{array}{l}8 \\
9 \\
\end{array}$ & & & 8 & & 10 & 25 & $\begin{array}{l}1 \\
2 \\
\end{array}$ & & $\begin{array}{c}18 \\
0 \\
\end{array}$ & & & 0 & & 3 & 26 & $\begin{array}{l}1 \\
7 \\
\end{array}$ & & 5 \\
\hline $\begin{array}{l}\text { Morales } \\
2016 \\
\end{array}$ & $\begin{array}{l}4 \\
0 \\
1 \\
\end{array}$ & 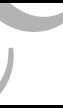 & & 49 & 13 & & $\begin{array}{c}16 \\
2 \\
\end{array}$ & $\begin{array}{l}9 \\
4 \\
\end{array}$ & & $\begin{array}{c}97 \\
4 \\
\end{array}$ & & & 25 & 10 & & $\begin{array}{c}27 \\
0 \\
\end{array}$ & $\begin{array}{l}2 \\
0 \\
6 \\
\end{array}$ & & 6 \\
\hline $\begin{array}{l}\text { Morales } \\
2018 \\
\end{array}$ & $\begin{array}{l}2 \\
8 \\
8 \\
\end{array}$ & & & 20 & 25 & $\begin{array}{c}11 \\
4 \\
\end{array}$ & $\begin{array}{c}10 \\
3 \\
\end{array}$ & 7 & & $\begin{array}{c}45 \\
2 \\
\end{array}$ & & & 2 & 27 & $\begin{array}{c}10 \\
5 \\
\end{array}$ & 89 & 1 & & 7 \\
\hline $\begin{array}{l}\text { Gauthier } \\
2018\end{array}$ & $\begin{array}{l}1 \\
0 \\
1 \\
\end{array}$ & $\begin{array}{c}65 / \\
36 \\
\end{array}$ & $\begin{array}{c}54 \pm \\
13 \\
\end{array}$ & 3 & 11 & & & 3 & & $\begin{array}{c}14 \\
6 \\
\end{array}$ & & & 5 & 18 & & & 2 & & 6 \\
\hline
\end{tabular}

Abbreviations: aPL: antiphospholipid; NOS, Newcastle-Ottawa Score; M/F: male/female; THR: thrombosis; NATHR: non allograft thrombosis; DGF delayed graft function;

AR: acute rejection; MFN: malfunction. 
Table 1. Cut-offs and mean levels of antiphospholipid antibodies reported by the studies included in the meta-analysis

\begin{tabular}{|c|c|c|c|c|c|c|c|c|c|c|c|c|c|c|}
\hline & & \multicolumn{6}{|c|}{$\mathrm{aCL}$} & \multicolumn{6}{|c|}{$a \beta^{2} G P I$} & \multirow{3}{*}{$\begin{array}{l}\mathrm{L} \\
\mathrm{A}\end{array}$} \\
\hline & & \multicolumn{2}{|c|}{ IgG GPL } & \multicolumn{2}{|c|}{ IgM MPL } & \multicolumn{2}{|c|}{ IgA APL } & \multicolumn{2}{|c|}{$\operatorname{lgG~u} / \mathrm{ml}$} & \multicolumn{2}{|c|}{$\operatorname{lgM~u} / \mathrm{ml}$} & \multicolumn{2}{|c|}{ IgA u/ml } & \\
\hline & & $\begin{array}{l}\text { aPL+ } \\
\text { ve }\end{array}$ & $\begin{array}{l}\text { aPL } \\
\text {-ve }\end{array}$ & $\begin{array}{l}\text { aPL+ } \\
\text { ve }\end{array}$ & $\begin{array}{l}\text { aPL- } \\
\text { ve }\end{array}$ & $\begin{array}{l}\text { aPL+ } \\
\text { ve }\end{array}$ & $\begin{array}{l}\text { aP } \\
\text { L- } \\
\text { ve }\end{array}$ & $\begin{array}{c}a P L+v \\
e\end{array}$ & $\begin{array}{l}\text { aPL } \\
\text {-ve }\end{array}$ & $\begin{array}{l}\text { aPL+ } \\
\text { ve }\end{array}$ & $\begin{array}{l}\text { aPL } \\
\text {-ve }\end{array}$ & $\begin{array}{l}\text { aPL+ } \\
\text { ve }\end{array}$ & $\begin{array}{l}\text { aPL- } \\
\text { ve }\end{array}$ & \\
\hline $\begin{array}{l}\text { Ducloux } \\
1997\end{array}$ & Cut-off & & 23 & & & & & & & & & & & \\
\hline $\begin{array}{l}\text { Vaidya } \\
1999\end{array}$ & Cut-off & & $>10$ & & $>15$ & & $>7$ & & & & & & & \\
\hline & $\begin{array}{l}\text { Mean+ } \\
\text { SD }\end{array}$ & $82 \pm 3$ & & $46 \pm 2$ & & & & & & & & & & \\
\hline $\begin{array}{l}\text { Grandtn } \\
\text { erova } \\
1999\end{array}$ & Cut-off & & $\begin{array}{l}5 S \\
D\end{array}$ & & $5 S D$ & & & & & & & & & \\
\hline $\begin{array}{l}\text { Wagenk } \\
\text { necht } \\
2000\end{array}$ & Cut-off & & + & & + & & + & & & & & & & \\
\hline $\begin{array}{l}\text { Vaidya } \\
2000\end{array}$ & Cut-off & & $>10$ & & $>15$ & & $>7$ & & & & & & & \\
\hline & $\begin{array}{l}\text { Mean+ } \\
\text { SD }\end{array}$ & $\begin{array}{c}39 \pm 2 \\
2\end{array}$ & & $\begin{array}{c}48 \pm 2 \\
5\end{array}$ & & & & & & & & & & \\
\hline $\begin{array}{l}\text { Friedma } \\
\text { n } 2001\end{array}$ & $\begin{array}{l}\text { Mean+ } \\
\text { SD }\end{array}$ & & + & & + & & & & & & & & & \\
\hline $\begin{array}{l}\text { Ducloux } \\
2003\end{array}$ & Cut-off & & 23 & & 23 & & $y$ & & & & & & & $\begin{array}{l}\mathrm{Y} \\
*\end{array}$ \\
\hline & $\begin{array}{l}\text { Mean+ } \\
\text { SD }\end{array}$ & $30 \pm 7$ & $9 \pm 4$ & & & & & & & & & & & $\begin{array}{l}\mathrm{Y} \\
@\end{array}$ \\
\hline Nampoo & Cut-off & & 23 & & 23 & & & & & & & & & \\
\hline & $\begin{array}{l}\text { Mean+ } \\
\text { SD }\end{array}$ & $\begin{array}{c}6.9 \pm \\
4.5 \\
\end{array}$ & $\begin{array}{l}4.8 \\
\pm 4 \\
\end{array}$ & $\begin{array}{c}1.6 \pm \\
1.9\end{array}$ & $\begin{array}{c}2.4 \pm \\
2.4 \\
\end{array}$ & & & & & & & & & \\
\hline $\begin{array}{l}\text { Mclntyre } \\
2003\end{array}$ & $\begin{array}{l}\text { Mean+ } \\
\text { SD }\end{array}$ & & & & + & & + & & & & & & & \\
\hline $\begin{array}{l}\text { Forman } \\
2004\end{array}$ & Cut-off & & 15 & & 15 & & & & & & & & & \\
\hline $\begin{array}{l}\text { Nybo } \\
2006\end{array}$ & Cut-off & & $\begin{array}{l}10 \\
\mathrm{u} / \\
\mathrm{ml}\end{array}$ & & $\begin{array}{c}10 \\
\mathrm{u} / \mathrm{ml}\end{array}$ & & & & & 10 & & & & $\begin{array}{l}\mathrm{Y} \\
@\end{array}$ \\
\hline $\begin{array}{l}\text { Fernand } \\
\text { ez } 2008\end{array}$ & Cut-gff & & $\begin{array}{c}>35 \\
U\end{array}$ & & $\begin{array}{c}>35 \\
U\end{array}$ & & & & & $3 S D$ & & & & \\
\hline $\begin{array}{l}\text { Ramirez } \\
2009\end{array}$ & Cut-off & & & & & & & & $>20$ & & $>20$ & & $>20$ & \\
\hline $\begin{array}{l}\text { Canaud } \\
2010\end{array}$ & Cut-off & & $>10$ & & $>10$ & & & & $\begin{array}{l}>0 \\
12\end{array}$ & & $\begin{array}{l}>0 . \\
12\end{array}$ & & & $y \bullet$ \\
\hline & $\begin{array}{l}\text { Mean+ } \\
\text { SD }\end{array}$ & $\begin{array}{c}46 \pm 2 \\
5\end{array}$ & & $19 \pm 6$ & & & & $\begin{array}{c}102 \pm \\
120\end{array}$ & & & & & & $y \bullet$ \\
\hline $\begin{array}{l}\text { Ghisdal } \\
2011\end{array}$ & Cut-off & & & & & & & & & & & & & $\mathrm{y}^{\bullet}$ \\
\hline $\begin{array}{l}\text { Vaidya } \\
2012\end{array}$ & Cut-off & & $<10$ & & $<15$ & & & & & & & & & $y \bullet$ \\
\hline Furmanc & Cut-off & & $>20$ & & $>20$ & & & & $>10$ & & $>10$ & & & $\mathrm{y} \bullet$ \\
\hline
\end{tabular}




\begin{tabular}{|c|c|c|c|c|c|c|c|c|c|c|c|}
\hline zyk 2013 & & & & & & & & & & & \\
\hline \multirow{2}{*}{$\begin{array}{l}\text { Serrano } \\
2014\end{array}$} & Cut-off & & & & & & & & & $>20$ & \\
\hline & $\begin{array}{l}\text { Mean+ } \\
\text { SD }\end{array}$ & & & & & & & & $\begin{array}{l}22 \pm \\
2.5\end{array}$ & $\begin{array}{c}5.1 \pm \\
0.4\end{array}$ & \\
\hline \multirow[t]{2}{*}{$\begin{array}{l}\text { Morales } \\
2015\end{array}$} & Cut-off & & $>20$ & & $>20$ & $\begin{array}{c}>2 \\
0\end{array}$ & $>20$ & $>20$ & & $>20$ & \\
\hline & $\begin{array}{l}\text { Mean+ } \\
\text { SEM }\end{array}$ & & & & & & & & $\begin{array}{l}22 \pm \\
9.4 \\
\end{array}$ & & \\
\hline $\begin{array}{l}\text { Morales } \\
2016\end{array}$ & Cut-off & & $>20$ & & $>20$ & $\begin{array}{c}>2 \\
0\end{array}$ & $>20$ & $>20$ & & $>20$ & \\
\hline $\begin{array}{l}\text { Morales } \\
2018\end{array}$ & Cut-off & & $>18$ & & $>18$ & & & & & & \\
\hline $\begin{array}{l}\text { Gauthier } \\
2018\end{array}$ & Cut-off & $<40$ & 10 & $<40$ & 10 & & & & & & \\
\hline
\end{tabular}

Abbreviations: aCL: anticardiolipin; aPL: antiphospholipid; $a \beta_{2} \mathrm{GPI}$ : antibeta2 glycoprtein-I; LA: lupus anticoagulant; + indicates that the authors only reported positivity with neither mean nor cut-offs. * not evaluable; @ evaluable as pre/post comparison; • data not extractable 


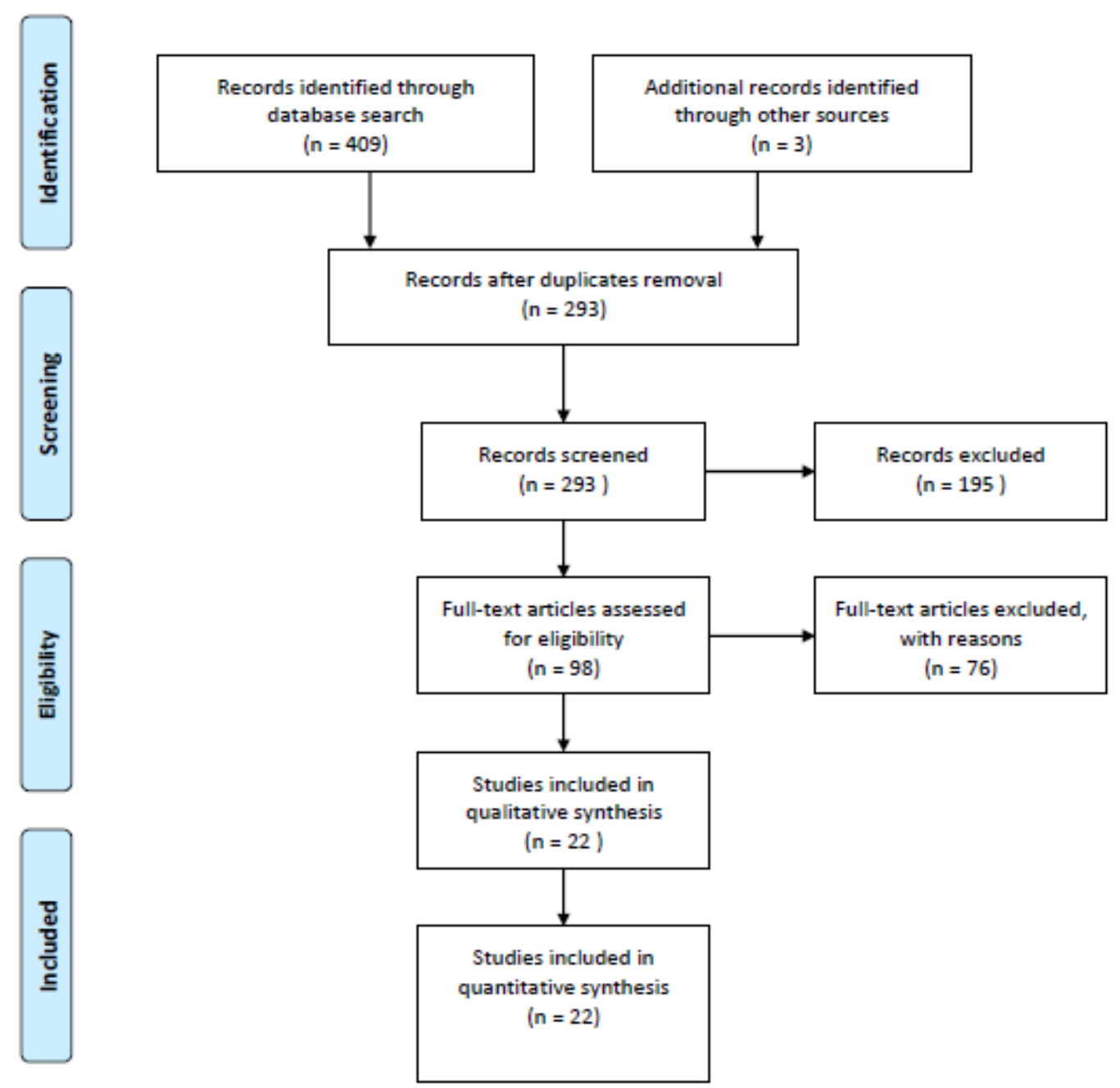

Reasons for exclusion of full text articles: systemic lupus erythematosus $n=14$, thrombotic microangiopathy $n=6$, thrombophilia peri-transplant $n=3$, end stage renal disease $n=4$, eculizumab in renal transplant $n=4$, rituximab in renal transplant $n=1$, prevalence study $n=3$, reviews and editorials $n=17$, case reports $n=5$, data replicated on different journals $n=4$, no absolute data provided $n=2$, no comparative outcome provided $n=4$, old paper in Italian $\mathrm{n}=1$, incomplete anticoagulation outcome in antiphospholipid antibody positive recipients $n=1$, not dealing with antiphospholipid antibody in renal transplant $n=7$.

Figure 1 